\title{
Lectotypification of Carex courtallensis (Cyperaceae) and notes on its morphology and habitat
}

Viji A.R., Geethakumary M.P., Deepu S., Pandurangan A.G.* and Shaju T.

Plant Systematics and Evolutionary Science Division, Jawaharlal Nehru Tropical Botanic Garden and Research Institute, Palode, Thiruvananthapuram, Kerala - 695 562, India.

Received: 2/15/2018; Revised: 2/27/2018; Accepted: 3/23/2018

\begin{abstract}
During the revision of Cyperaceae in Western Ghats, a specimen was collected from Chemunji hills, Thiruvananthapuram District, Kerala, identified as Carex courtallensis Nees ex Boott, a species recollected after a gap of 150 years, about $50 \mathrm{~km}$ away from the type locality. On examining the protologue of the species and later works, along with specimens housed at various herbaria, we identified the need for lectotypification of the species. The present paper provides detailed description, photographs and relevant notes on the species based on recent collections.
\end{abstract}

Key words: Agasthyamala Biosphere Reserve, Kerala, Tamil Nadu, Lectotype

\section{Introduction}

Carex Linnaeus (1753: 972) is one of the largest and widespread genera with 2000 species in the world, roughly $40 \%$ of the family by species (Reznicek, 1990; Govaerts et al., 2016; Global Carex Group, 2015). It has a cosmopolitan distribution particularly in temperate and cold regions at higher altitudes in the tropics (Deng, 2013). The genus is represented by c. 160 species in India, as it prefers cold and moist habitats of high lands, it has reached its greatest diversity in the Kashmir Himalaya and Western Ghats and represents one of the largest genera in these regions (Karthikeyan et al., 1989; Prasad \& Singh, 2002; Viji \& Pandurangan, 2015).

Field exploration in the Agasthyamala Biosphere Reserve of Western Ghats, India yielded some interesting specimens of Carex from Chemunji hills, Thiruvananthapuram, Kerala, which showed apparent similarity with Carex speciosa complex. On detailed observation with literature and authentic specimen (E00393452 Isosyntype!), it was identified as C. courtallensis Nees ex Boott (in Boott 1858: 52) belonging to section Radicales (Kuek.) Nelmes. On examining the protologue of the species and a later revision of the genus, along with specimens housed at various herbaria, we identified the need for lectotypification of the species.

Robert Wight was a Scottish surgeon and botanist who spent 30 years in India. During his stay, he made extensive collections from South India (18191853) and sent them to Glasgow to be studied by William Hooker and George Arnott Walker, most of them later forming part of Arnott's herbarium (now in E). C. courtallensis was recognized by Nees von Esenbeck based on the collections of Robert Wight from Courtallum, part of the erstwhile Travancore hills (specimen Wight 991, 15 th August 1835). There

*Corresponding Author:

Pandurangan A.G.,

Jawaharlal Nehru Tropical Botanic Garden and Research Institute,

Palode, Thiruvananthapuram, Kerala - 695 562, India.

E-mail: agpandurangan@gmail.com is no manuscript description of $C$. courtallensis in the Nees volume (Wight's contribution) and the published description is by Boott (1858) in his monumental work on Illustrations of the Genus Carex (Noltie, pers. comm.).

The first full taxonomic treatment of sedges in India was given by C. B. Clarke (1894) in the Flora of British India, wherein 142 species of Carex under 7 sections in 2 subgenera were described. Subsequently no serious attempt was made on taxonomic studies of this genus in India and $C$. courtallensis remained unknown to taxonomists due to either misidentification as C. speciosa or lack of sufficient materials in regional herbaria $\mathrm{MH}, \mathrm{CALI}$, TBGT, KFRI, UCT, BLAT, RHT), which was apparent during our search for the materials of $C$. courtallensis.

Dai et al. (2010) while revising the genus Carex in the Flora of China treated C. courtallensis as a separate species based on the collection from Yunnan. Recently Jin et al. (2015) followed Kükenthal (1909) and reduced its status to Carex speciosa var. courtallensis with C. speciosa subsp. dilatata Noltie (1993: 197) as its synonym. They cited 7 specimens from Sichuan and Yunnan. Critical examination of type specimens, protologues, wide range of materials housed at different herbaria ( $\mathrm{K}, \mathrm{E}, \mathrm{BM}, \mathrm{P}, \mathrm{PE}, \mathrm{KUN}, \mathrm{KYO}$, TBGT) and fresh collections by the authors nearer to the type locality suggests that $C$ courtallensis is quite distinct from $C$. speciosa and should be recognised as a separate species. The former can be differentiated from C. speciosa by plants up to $90 \mathrm{~cm}$ tall (vs. up to $50 \mathrm{~cm}$ tall), Rhizome $>4 \mathrm{~cm}$ (vs. rhizome less than 4 $\mathrm{cm}$ ), peduncles enclosed in bract sheaths (vs. peduncles not enclosed), nutlets stipitate (vs. nutlet not stipitate), agreeing with the observations by Raymond (1959). 


\section{Lectotypification}

Three sheets of C. courtallensis belonging to Wight's collection were traced out, of which two sheets are at Edinburgh herbarium and one at Kew herbarium. It appears that all the specimens were part of Wight's collection send to Sir W. J. Hooker while he was Regius Professor of Botany at Glasgow University. The two sheets at $\mathrm{E}$ are from Walker-Arnott's herbarium, which was put on permanent loan to $\mathrm{E}$ in 1966. The sheet housed at Kew consists of 2 specimens, bearing the handwriting of Boott with collection data mentioned in the protologue, of which the right-hand specimen (K000061657!) exactly matches the illustration provided by him; which is designated here as lectotype. Both the specimens in the sheet are possibly part of same collection and should have been given two separate barcodes overlooking the Wight's numbering system. The confusion should have occurred due to the presence of a vertical red line in the middle of the sheet separating one plant from the other and, at the inferior left part there are 2 numbers 1835/991, the capsule at the centre has a number 991, and they should have assumed that the other number is for the other plant at the left and was given two barcodes. Incidentally the number on the capsule was written by Nelmes who borrowed this sheet from Glasgow and kept a few utricles and wrote the pencil annotation on that capsule. Here, 991 is a field number given by Wight, and which should be cited as '[1835.]991' (because he re-used the same number in different years) (Noltie, 2005). Since both specimens were given two barcodes we are considering the right-hand specimen (K000061657!) as lectotype, and left-hand specimen (K000999016!) and sheets in $\mathrm{E}$ as isolectotypes in accordance with article 9.2 of ICN (McNeill et al., 2012).

\section{Taxonomic treatment}

Carex courtallensis Nees ex Boott, Ill. Gen. Carex 1:52, t. 138. 1858.

Type: INDIA. Tamil Nadu: Tirunelveli distr., Courtallum hills, 15 August 1835, Wight [1835.]991.

- lectotype (designated here) K000061657 (right hand specimen)!; isolectotypes: K000999016 (left hand specimen)!, E00393452!, E00393453! - Figure 1A-C.
Perennial herbs, 35-80 cm tall. Rhizomes elongate, 5$15 \times 2-3 \mathrm{~cm}$. Culms tufted, 1-4 together, 1.5-2.5 $\mathrm{mm}$ thick, triquetrous, stiff, smooth. Leaves radical; sheath dark brown, 3-10 cm long; blades flat, 0.8-2 $\mathrm{cm}$ wide, smooth, soft. Inflorescence of terminal and auxiliary spikes; involucral bracts leaf-like, longer than inflorescence, $10-25 \times 0.8-1.2 \mathrm{~cm}$ wide, flat, long sheathed. Spikes 2-6, androgynous, lowest one borne at middle part or base of the culm, cylindrical, 4-6 × 0.3-0.5 cm, densely flowered; male part $1-2 \times$ $0.1-0.3 \mathrm{~cm}$; female part $2-5 \times 0.5-1 \mathrm{~cm}$. Glumes green, ovate to ovate-oblong, 3-4 mm long, papery, uni-nerved, margin ciliate, apex rounded to obtuse. Stamens 3; anthers ca. $0.5 \mathrm{~mm}$ long. Ovary obovoid; style ca. $2 \mathrm{~mm}$ long; stigmas 3. Utricle green, elliptic, slightly inflated, trigonous, 4.5-5.5 × 2-2.8 mm, papery, glabrous, many veined, base attenuate, margins narrowly winged, ciliate, apex abruptly contracted into a short beak, orifice 2-toothed. Nut brown, obovate to oblong, trigonous, 2.5-3.5 $\times 1.5-$ $2 \mathrm{~mm}$, shortly stipitate, apex rounded. (Figure 1D, Figure $2 \& 3$ ).

Phenology: Flowering and fruiting was observed from May to December.

Note: The present collection from Chemunji, is a report of this little-known species after a lapse of 150 years about $50 \mathrm{~km}$ away from its type locality. The locality is characterised by low elevation montane evergreen forests and a fairly good population of this species is seen at an altitude of 1000-1200 m above m.s.l. Live collections are maintained in the field gene bank of Jawaharlal Nehru Tropical Botanic Garden and Research Institute.

Specimens examined: INDIA. Kerala, Thiruvananthapuram Distr., Chemunji, \pm 1100 m, 26 October 2002, M. P. Geethakumary 48420; ibid., 11 December 2014, A. R. Viji 72320; ibid., 11 December 2014, Deepu Sivadas 78700 (TBGT). 

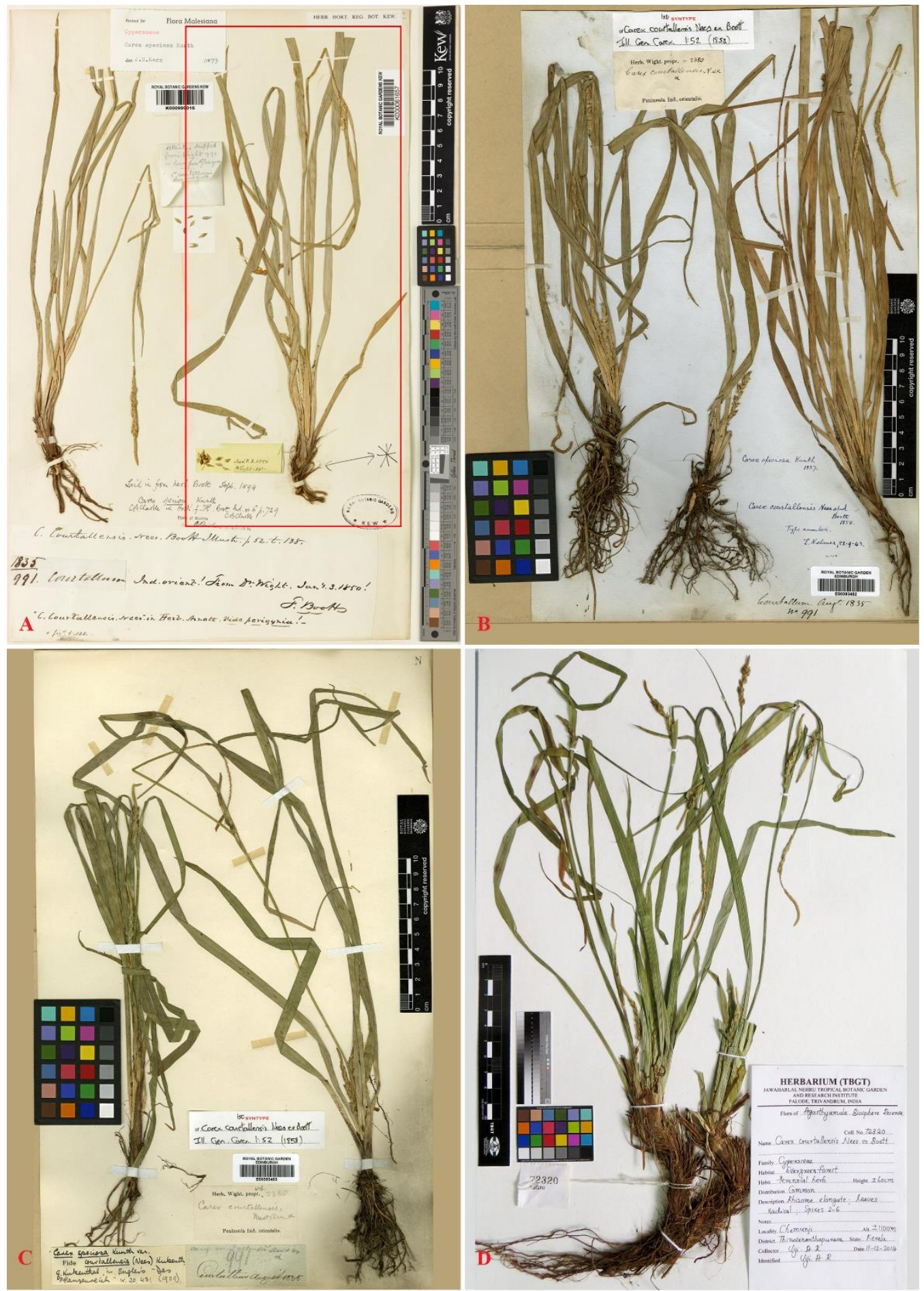

Figure 1. A-C. Carex courtallensis Nees ex Boott A. Lectotype - K000061657 (right hand specimen)! [( $)$ the Board of Trustees of the Royal Botanic Garden, Kew]; B. Isolectotype - E00393452! [C the Board of Trustees of the Royal Botanic Gardens, Edinburgh]; C. Isolectotype - E00393453! [C the Board of Trustees of the Royal Botanic Gardens, Edinburgh]; D. Recent collection - A. R. Viji 72320 (TBGT!) 


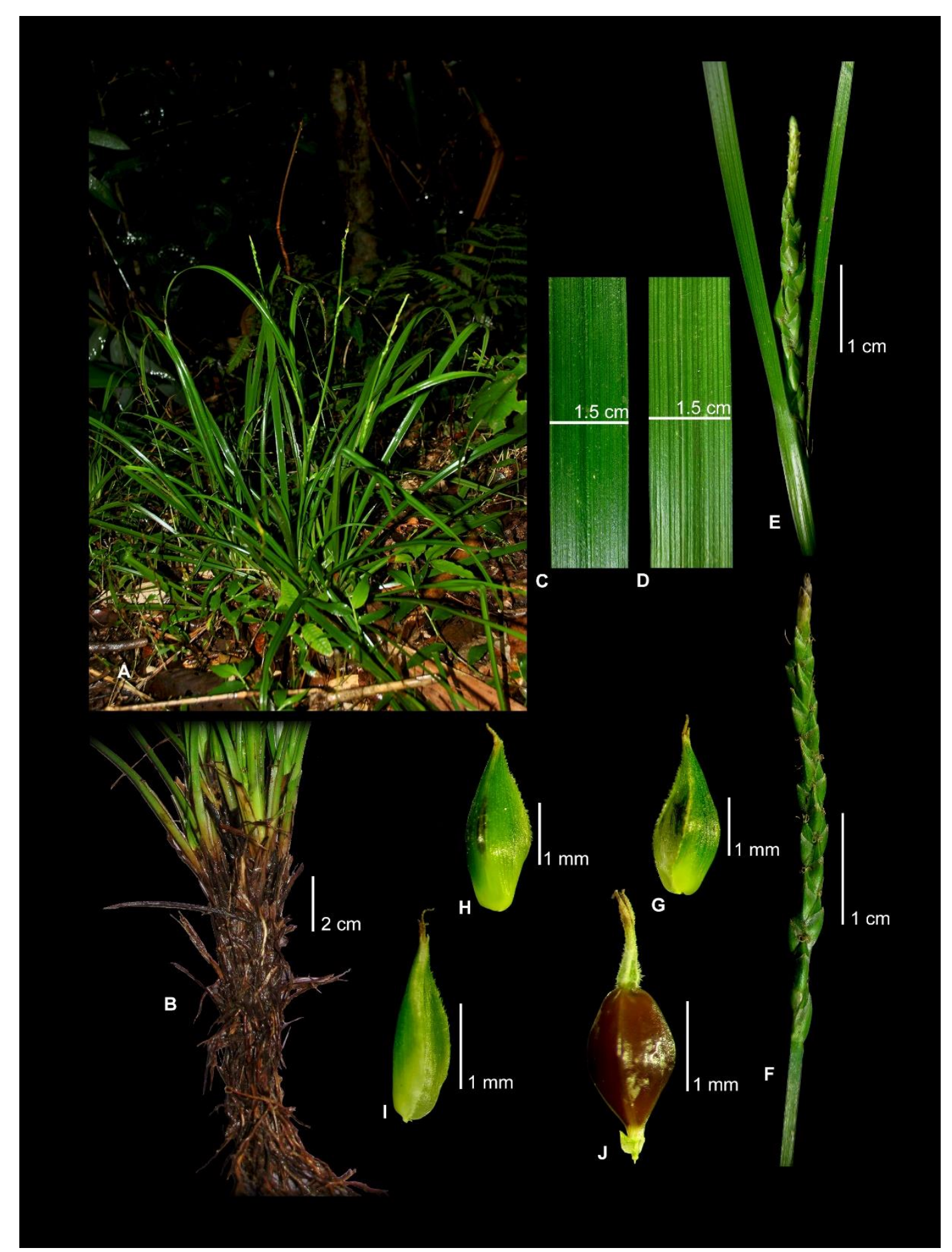

Figure 2. Carex courtallensis Nees ex Boott A. Habit; B. Rhizome; C-D. Portion of leaf; E-F. Spike; GI. Utricle; J. Nut. Photos Deepu S. from A. R. Viji 72320 


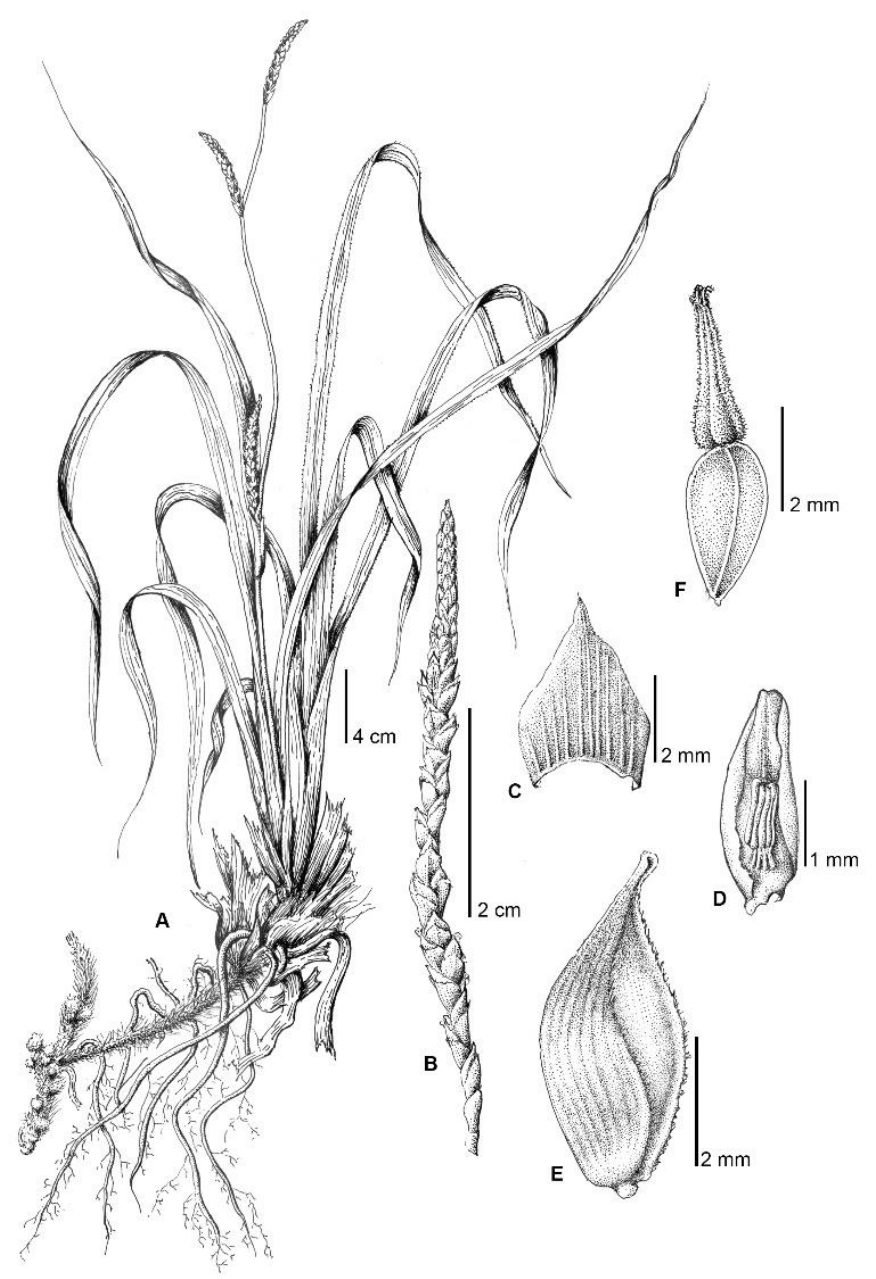

Figure 3. Carex courtallensis Nees ex Boott A. Habit; B. Spike; C. Glume; D. Glume with Stamens; E. Utricle; F. Nut. Drawn by T. Shaju

\section{Acknowledgements}

The authors are grateful to Dr Gordon C. Tucker, Eastern Illinois University, USA for confirming the identity of the specimen. Thanks, are also due to Dr Henry Noltie, Royal Botanic Garden Edinburgh and Dr Tim Utteridge and Maria Alvarez of Royal Botanic Gardens, Kew for their inputs; and to the Boards of Trustees of $\mathrm{K}$ and $\mathrm{E}$ for use of the type images. The curators of K, E, C, BM, P, PE, KUN, KYO, TBGT, MH, CALI, KFRI, UCT, BLAT and RHT are duly acknowledged for granting access to the herbarium materials. The State Forest Authorities of Kerala are acknowledged for giving permission to conduct field studies.

\section{References}

1. Boott F, Illustrations of the genus Carex. Pt. 1. tt.1200, William Pamplin, London, 1858, pp. 1-74.

2. Clarke CB, Carex. In: Hooker, J. D (ed.) Flora of British India Vol 6., L. Reeve and Company, London, UK, 1894, pp. 699-748.
3. Dai LK, Koyama T, Carex L. sect. Radicales In: Wu, Z. Y., Ravan, P. H. \& Hong D. Y. Flora of China Vol 23, Science Press, Beijing \& Missouri Garden Press, St. Louis, 2010, pp. 285-461.

4. Deng Y, Valid publication of the name Carex benryi (Cyperaceae) from Asia, Phytotaxa, 2013, 146(1), 3234.

5. Global Carex Group, Making Carex monophyletic (Cyperaceae, tribe Cariceae): a new broader circumscription, Bot J Linn Soc, 2015, 179, 1-42.

6. Govaerts R, Simpson DA, Brahl J, Egorova T, Goetghebeur P, Wilson K, World Checklist of Cyperaceae. Royal Botanic Gardens, Kew, published on the Internet; http://apps.kew.org/wcsp/ Retrieved 2016-07-22.

7. Jin XF, Cen J, Hahn M, Lu Y, He J, Notes on Carex (Cyperaceae) from China (II): a taxonomic revision of sect. Radicales (Kuek.) Nelmes, Phytotaxa, 2015, 217(2), 117-132.

8. Karthikeyan S, Jain SK, Nayar MP, Sanjappa M, Florae Indicae Enumeratio: Monocotyledonae, 
Botanical Survey of India, Calcutta, India, 1989, pp. 33-43.

9. Kükenthal G, Cyperaceae: Caricoideae. In: Engler, W. (ed.) Das Pflanzenreich IV.20. Heft 38, Engelmann, Leipzig, 1909, pp. 1-824.

10. Linnaeus C, Species Plantarum. Salvius, Stockholm, 1753, $972 \mathrm{pp}$.

11. McNeill J, Barrie FR, Buck WR, Demoulin V, Greuter W, Hawksworth DL, Herendeen PS, Knapp S, Marhold K, Prado J, Prud'homme van Reine WF, Smith GF, Wiersema JH, Turland NJ (eds.), International code of nomenclature for algae, fungi, and plants (Melbourne Code): Adopted by the eighteenth International Botanical Congress, Melbourne, Australia, July 2011, Regnum Vegetabile, 2012, 154, 1-274.

12. Noltie HJ, Notes relating to the flora of Bhutan: XXI Carex (Cyperaceae), Edinburgh Journal of Botany, 1993, 50, 185-206.

13. Noltie HJ, Botany of Robert Wight. Chapter 7, A.R.G. Gantner, 2005,276 pp.
14. Prasad VP, Singh NP, Sedges of Karnataka (India) (Family Cyperaceae), Scientific publishers, Jodhpur, 2002, 354 pp.

15. Raymond $\mathrm{M}$, Carices Indochinenses necnon Siamenses, Mémoires du Jardin Botanique Montréal, $1959,53,78$.

16. Reznicek AA, Evolution in Sedges (Carex, Cyperaceae), Canadian Journal of Botany, 1990, 68, 1409-1432.

17. Viji AR, Pandurangan AG, On the occurrence of little known sedge, Carex walkeri from Nilgiri, Int J Pure App Biosci, 2015, 3(2), 105-107.

\section{Cite this article as:}

Viji, A.R., Geethakumary, M.P., Deepu, S., Pandurangan, A.G. \& Shaju, T. Lectotypification of Carex courtallensis (Cyperaceae) and notes on its morphology and habitat. Annals of Plant Sciences 7.4 (2018) pp. 2172 2177

do $\mathrm{http://dx.doi.org/10.21746/aps.2018.7.4.17}$ 